\title{
Occurrence of ketone bodies in the urine of cows during the first three months after calving and their association with milk yield
}

\author{
Ewa Januś and Danuta Borkowska \\ Department of Animal Breeding and Use, Faculty of Agricultural Sciences in Zamość, University of Life Sciences in \\ Lublin, Poland
}

\begin{abstract}
The aim of the study was to assess the effect of lactation number, month after calving, body condition at calving, milk yield and feeding season on the frequency and intensity of occurrence of ketone bodies in the urine during the first trimester after calving of Polish Holstein-Friesian cows cows with average annual milk yield of about $7000 \mathrm{~kg}$. It was also evaluated how the presence of ketone bodies in the urine of cows was associated with their milk production and the course of lactation. 479 urine samples were collected from the cows. The samples were tested using KRULAB test strips. The influence of the presence of ketone bodies on milk yield in 150 lactations and in 1797 milk samples was also evaluated. It was found that $36.2 \%$ of urine samples contained ketone bodies that could indicate various forms of ketosis. The frequency and intensity of the occurrence of ketone bodies in the urine was significantly influenced by the cows' body condition at calving, milk yield during standard lactation, the day the urine samples were collected and feeding season. The presence of ketones in the urine had little effect on milk yield in standard and complete lactations. Cows whose urine contained ketone bodies had significantly higher daily milk yield up to the sixth month of lactation. This could indicate that cows with high production potential are more susceptible to ketosis. The occurrence of ketones in the urine had a negative effect on the lactation curves of the cows tested.
\end{abstract}

Keywords: cows, ketone bodies, urine, milk yield, course of lactation

Abbreviations: $B C S$ : body condition score, DM: dry matter

Archiv Tierzucht 56 (2013) 57, 581-588

doi: $10.7482 / 0003-9438-56-057$

Corresponding author:

Ewa Januś; email: ewa.janus@up.lublin.pl

Department of Animal Breeding and Use, Faculty of Agricultural Science of Zamość, University of Life Sciences in Lublin, Szczebrzeska 102, 22-400 Zamość, Poland

() 2013 by the authors; licensee Leibniz Institute for Farm Animal Biology (FBN), Dummerstorf, Germany. This is an Open Access article distributed under the terms and conditions of the Creative Commons Attribution 3.0 License (http://creativecommons.org/licenses/by/3.0/).
Received: 18 September 2012

Accepted: 19 March 2013 Online: 26 April 2013 


\section{Introduction}

In 2011 an increase was once again noted in the milk yield of the active cow population in Poland. Compared with 2010, milk yield increased by $155 \mathrm{~kg}$ (from 6980 to $7135 \mathrm{~kg}$ ), while the number of cows undergoing use value assessment increased by $26613-2 \%$ (PFCB \& DF 2012). The continually growing production potential of dairy cows and the use of increasingly modern technologies lead to metabolic and infectious diseases (Mordak et al. 2009). An unbalanced diet, which is not suited for the cows' needs and the physiological state, contributes to the occurrence of metabolic diseases. (Filar 2001). Among metabolic disorders affecting cattle, ketosis, which can affect $50-80 \%$ of a herd, is the most common (Kondracki et al. 1996). It usually occurs between the third and sixth week of lactation and results from an imbalance between energy requirements and energy uptake. This leads to increased lipolysis and increased concentration of free fatty acids in the blood, which together with the acetyl-CoA produced from them are precursors of ketone compounds ( $\beta$-hydroxybutyrate, acetoacetic acid, acetone) (Filar 2001, Markiewicz et al. 2004, Raś 1999). In conditions of normal carbohydrate and fat metabolism, the acetyl-CoA formed in the liver is almost completely oxidised to $\mathrm{CO}_{2}$ and $\mathrm{H}_{2} \mathrm{O}$ in the Krebs cycle and a considerable amount of energy required by the organism is released. When there is a negative energy balance, due to a deficiency of oxaloacetic acid formed from glucose, acetyl-CoA is used in synthesis of ketone compounds. They are found in urine, milk and exhaled air (Filar 1994).

In modern dairy cow barns many tools are used that make herd management relatively simple. These include tests for determining the presence of ketone bodies in urine and milk (Geishauser et al. 2000, Januś \& Borkowska 2008, Krogh et al. 2011). When these metabolites are identified it is possible to quickly eliminate their cause and in some cases to begin treatment.

The aim of the study was to assess the effect of selected factors on the frequency and intensity of occurrence of ketone bodies in the urine of Polish Holstein-Friesian cows in the first trimester after calving. It was also analysed how the presence of ketone bodies in the urine was associated with milk production and the course of lactation.

\section{Material and methods}

The study was carried out over a four-year period in a herd of 70 Black-and-White Polish Holstein-Friesian cows. Their average annual milk yield was about $7000 \mathrm{~kg}$ of milk. The milk performance of the cows was evaluated based on test-day milking carried out once a day in a month (AT4 method).

The cows were kept in a tie-stall barn. In the summer they were pastured, but this served mainly for exercise and did not form the basis of their diet during this period. Feed rations did not include pasture forage. In both winter and summer the cows were fed silage from maize and wilted grass, hay and spent grain. In the winter they were also given sugar beet pulp silage and lucerne silage as roughage feed. Cows whose daily milk yield exceeded ten $\mathrm{kg}$ of milk received compound feed consisting of wheat bran, rapeseed and barley meal, high-energy concentrate and premix. The cows' diet (both in summer and in winter) in the first three weeks after calving met $89 \%$ (week two), $90 \%$ (week one) and 99\% (week three) of their energy demands and in subsequent weeks from $101 \%$ to $104 \%$. $100 \%$ of protein 
demand was not met in the first two weeks of lactation, while in subsequent weeks it was slightly exceeded (3-4\%).

During the four years the cows were kept in the herd, the body condition of each cow was determined in the last two weeks of the dry period according to the 5-point body condition score (BCS) system (Wildman et al. 1982), accurate to within 0.5 points. Next, in the first three months after calving, urine samples were collected on the day of test-day milking to test the presence of ketone bodies. The samples were collected once a month during urination. The assays were performed using KRULAB multiparameter test strips (KRUUSE, Langeskov, Denmark). The strip was immersed in the sample for $1 \mathrm{~s}$, tissue paper was used to absorb the excess urine and after $60 \mathrm{~s}$ the colour of the test area (active reagent: nitroprusside) was observed. Based on the colour reaction, the following results for the presence of ketone bodies and their intensity were distinguished: none (-), traces (+/-), positive $(+)$ and strongly positive $(++/+++)$. A total of 479 urine samples were tested, collected from 107 cows.

SAS 9.1 software (SAS Institute Inc., Cary, NC, USA) was used for statistical calculations. The $\chi^{2}$ test of independence was used to analyse the occurrence of different results for the ketone body assay depending on lactation number (1, 2-3, and 4 and higher), month after calving (1, 2 and 3), body condition at calving (BCS up to 2.5, 3.0-3.5, and >3.5), milk yield in standard lactation (up to $5500 ; 5501-6500$ and $>6500 \mathrm{~kg}$ milk), daily yield on the days urine was collected (up to 22.0, 22.1-27.0 and $>27.0 \mathrm{~kg}$ milk) and feeding season (summer - MayOctober; winter - November-April).

In addition, variance analysis (PROC GLM) was used to evaluate the effect of the presence of ketone bodies in the urine on the cows' milk yield in standard and complete lactation and on the course of lactation. Data obtained from breeding documentation were used for this analysis: daily milk yield in 1797 test-day milkings and productivity (milk yield and composition) in 150 lactations. These lactations were divided into two groups depending on the results of the test for the presence of ketone bodies. The first consisted of lactations of cows in whose urine no ketone bodies were noted in any test (designated »no«). The second group comprised lactations in which at least one urine test result was other than negative (designated as "yes«). Averages for milk yield (also converted to yield per day of milking) and for fat and protein values were calculated in both groups (i.e. "yes« and »no«), as well as the average content of these components in milk obtained in standard and complete lactations and daily yield in successive months of lactation. These averages were used to compare the productivity of cows that had not suffered from ketosis and those which had been diagnosed with it. The significance of the differences between average values was determined using Duncan's test at significance levels $P \leq 0.01$ and $P \leq 0.05$.

\section{Results and discussion}

In the herd analysed, ketone bodies that could indicate various forms of ketosis were found to be present in the urine in 173 cases (36.2\%) (Table 1). In the samples containing ketone bodies, traces (+/-) of the metabolites were noted most often (20.1\%). Positive results were found in $10.4 \%$ of the samples and strongly positive results in 5.6\%. McArt et al. (2011) report that in some high-yield herds subclinical ketosis occurs in about $80 \%$ of cows at the beginning of lactation, while the clinical form is noted in 2 to $15 \%$. 
Table 1

Occurrence of ketone bodies in cow urine taking into account the effect of the factors analysed

\begin{tabular}{|c|c|c|c|c|c|c|}
\hline \multirow[t]{2}{*}{ Factor } & & \multicolumn{4}{|c|}{$\begin{array}{l}\text { Results of the test for the presence of ketone bodies } \\
\text { in the urine - number (\%) of samples }\end{array}$} & \multirow{2}{*}{$\begin{array}{l}\text { Value } \\
\text { for } \\
\chi^{2} \text { test }\end{array}$} \\
\hline & & $(-)$ & $(+/-)$ & $(+)$ & $(++/+++)$ & \\
\hline Lactation number & $\begin{array}{l}1 \\
2-3 \\
>3\end{array}$ & $\begin{array}{r}121(69.9) \\
116(58.3) \\
69(64.5)\end{array}$ & $\begin{array}{l}32(18.5) \\
41(20.6) \\
23(21.5)\end{array}$ & $\begin{array}{rr}14 & (8.1) \\
29 & (14.6) \\
7 & (6.5)\end{array}$ & $\begin{array}{rr}6 & (3.5) \\
13 & (6.5) \\
8 & (7.5)\end{array}$ & 10.71 \\
\hline Month of lactation & $\begin{array}{l}1 \\
2 \\
3\end{array}$ & $\begin{array}{r}90(62.5) \\
105(67.3) \\
111(62.0)\end{array}$ & $\begin{array}{l}26(18.1) \\
28(18.0) \\
42(23.5)\end{array}$ & $\begin{array}{lr}19 & (13.2) \\
15 & (9.6) \\
16 & (8.9)\end{array}$ & $\begin{aligned} 9 & (6.2) \\
8 & (5.1) \\
10 & (5.6)\end{aligned}$ & 5.40 \\
\hline $\mathrm{BCS}$, pts at calving & $\begin{array}{l}\text { up to } 2.5 \\
3.0-3.5 \\
>3.5\end{array}$ & $\begin{array}{r}40(85.1) \\
146(63.7) \\
120(59.1)\end{array}$ & $\begin{array}{rr}4 & (8.5) \\
54 & (23.6) \\
38 & (18.7)\end{array}$ & $\begin{array}{rr}2 & (4.3) \\
24 & (10.5) \\
24 & (11.8)\end{array}$ & $\begin{array}{r}1(2.1) \\
5(2.2) \\
21(10.4)\end{array}$ & $24.76^{*}$ \\
\hline $\begin{array}{l}\text { Milk yield in } \\
\text { standard lactation, } \\
\mathrm{kg} \text { of milk }\end{array}$ & $\begin{array}{l}\geq 5,500 \\
5,501-6,500 \\
>6,500\end{array}$ & $\begin{array}{r}119(76.3) \\
104(60.8) \\
83(54.6)\end{array}$ & $\begin{array}{l}22(14.1) \\
36(21.1) \\
38(25.0)\end{array}$ & $\begin{array}{rr}9 & (5.8) \\
18 & (10.5) \\
23 & (15.1)\end{array}$ & $\begin{array}{rr}6 & (3.8) \\
13 & (7.6) \\
8 & (5.3)\end{array}$ & $19.31^{*}$ \\
\hline Daily milk yield, kg & $\begin{array}{l}\text { up to } 22.0 \\
22.1-27.0 \\
>27.0\end{array}$ & $\begin{array}{r}107(73.8) \\
116(61.1) \\
83(57.6)\end{array}$ & $\begin{array}{l}24(16.6) \\
45(23.7) \\
27(18.8)\end{array}$ & $\begin{array}{rr}6 & (4.1) \\
17 & (8.9) \\
27 & (18.8)\end{array}$ & $\begin{array}{rr}8 & (5.5) \\
12 & (6.3) \\
7 & (4.8)\end{array}$ & $32.06^{*}$ \\
\hline Feeding season & $\begin{array}{l}\text { summer } \\
\text { winter }\end{array}$ & $\begin{array}{l}167(68.2) \\
139(59.4)\end{array}$ & $\begin{array}{l}35(14.3) \\
61(26.1)\end{array}$ & $\begin{array}{l}26(10.6) \\
24(10.2)\end{array}$ & $\begin{array}{ll}17 & (6.9) \\
10 & (4.3)\end{array}$ & $11.23^{*}$ \\
\hline Total & & $306(63.8)$ & $96(20.1)$ & $50(10.5)$ & $27(5.6)$ & - \\
\hline
\end{tabular}

*value for the $\chi^{2}$ test significant at $P \leq 0.01$

The values of the $\chi^{2}$ test indicate that the occurrence of ketone bodies in the urine during the first trimester of lactation is significantly $(P \leq 0.01)$ influenced by body condition at calving, milk yield over 305 days and during test-day milking and feeding season. In cows whose body fat reserves before calving had the lowest scores (BCS up to 2.5), positive and strongly positive results were obtained in three cases $-6.4 \%$. Where body condition was 3.0-3.5, the percentage of such samples (i.e. in total positive and strongly positive) was $12.7 \%$ and in cows with the highest scores (>3.5) it was $22.2 \%$. A study by Gillund et al. (2001) in a population of Norwegian cattle found a greater risk of ketosis in cows whose body condition was at least BCS 3.5. Kuczaj et al. (2010) report that the risk of ketosis and hepatic steatosis increases during the calving period. Cows that take in too little dry matter before and after calving are predisposed to ketosis, particularly those with more body fat. Januś et al. (2007) reported that in cows whose body condition is too high during the dry period (BCS>4.0), the negative energy balance after calving was greater and lasted longer. The values of betahydroxybutyric acid in blood observed by Kupczyński et al. (2011) were both before parturition and up to the third week of lactation higher with higher prepartum condition. Minor et al. (1998) report that an increase in non-fibre carbohydrates to $44 \%$ DM led to a $27 \%$ increase in dry matter intake of cows before calving and a $57 \%$ increase in energy intake. These cows had lower levels of free fatty acids and beta-hydroxybutyric acid in the serum and lower levels of triglycerides in the liver. Bell (1995) determined that significant changes usually occur in the metabolism of cows during the transitional period; hepatic gluconeogenesis increases and glucose consumption decreases in peripheral tissues. Mobilisation of fatty 
acids from tissues and amino acids from muscles increases; after calving these processes are strongly accelerated. Smith et al. (1997) demonstrated that the incidence of ketonemia and clinical ketosis was the same for obese and normal cows, but on the basis of changes in blood and liver composition, the incidence of ketosis could probably increase if obese cows were overfed throughout the entire dry period. In the present study, the percentage of samples that were tested negative for ketone bodies decreased (by $26 \%$ ) as body condition score increased. This could result from the utilisation of body fat reserves for milk production leading to the appearance of ketone bodies in the urine.

The percentage of samples in which no ketone bodies were noted also decreased as milk yield in standard lactation (by $21.7 \%$ ) and per day (by $16.2 \%$ ) increased. The total share of positive and strongly positive results for the ketone body assay increased with milk yield in standard lactation $-9.6 \%, 18.1 \%$ and $20.4 \%$ for the three levels of yield. This percentage also increased with daily milk yield $-9.6 \%, 15.2 \%$ and $23.6 \%$. Stengärde et al. (2012) report that keeping dry cows in one group appear to be an important risk factor for a high incidence of clinical ketosis. Other research has also shown an association between high milk yield and increased susceptibility to ketosis (McArt et al. 2011). Staufenbiel et al. (2003) reported that negative energy balance is getting more intense and prolonged with increasing milk yield. In these authors' opinion the conditional nadir should not decline below $13 \mathrm{~mm}$ back fat thickness on herd average to reach a high production level without an increasing incidence of health disorders,. According to de Boer et al. (1985), a lactation ketosis results of more factors than solely a severe energy deficit. Difficulties in synthesising cortisol when energy demands increase in peak lactation could be one possible reason.

The analysis of the effect of the feeding season on the presence of ketone bodies in the urine revealed fundamental differences in the percentage of samples that were negative (8.8\% difference), questionable (11.8\%) and strongly positive (2.6\%). Questionable results were more often obtained in the winter months and negative or strongly positive results in the summer. The higher percentage of urine samples containing ketone bodies during the winter may result from ketogenic feed (Filar 1994). The frequency and intensity of occurrence of ketone bodies in the urine of cows was not affected by the lactation number or the month after calving. Østergaard \& Gröhn (1999) found that the incidence of ketosis increased with parity ( $2 \%$ for parity 1 and $20 \%$ for parity $\geq 2$ ). A significant correlation between lactation number and occurrence of ketosis was also indicated by Fleischer et al. (2001).

Table 2 presents data on the yield and composition of milk during standard and complete lactations. The data show that the presence of ketone bodies in the urine during the first trimester did not reduce milk yield in the standard lactation. This is consistent with a study by Rajala-Schultz et al. (1999), who found that cows with ketosis yielded more milk over the entire lactation than healthy ones. In the present study, cows in whose urine ketone bodies were noted produced more milk (by $330 \mathrm{~kg}$ ), as well as more fat and protein (by 12 and $6 \mathrm{~kg}$, respectively). The differences between these groups were statistically insignificant in the case of fat content in the milk. Significant differences were noted for milk yield per day in milk $(P \leq 0.05)$ and for protein content in the milk $(P \leq 0.01)$. Complete lactations during which no ketone bodies were noted in the urine lasted 28 days longer. Milk yield in these lactations was $68 \mathrm{~kg}$ higher, while fat and protein contents were 5 and $6 \mathrm{~kg}$ higher compared with lactations in which ketone bodies were noted in the urine in the first trimester after calving. 
Fat and protein content in the milk were also higher (by 0.20 and $0.09 \%$, respectively). The differences between these groups were statistically insignificant. The difference in milk yield per day in milk, which was $1.1 \mathrm{~kg}$ lower in the groups that were tested negative for ketone bodies, was also insignificant

Table 2

Milk yield in standard and complete lactations of cows with positive and negative results for the ketone bodies

\begin{tabular}{|c|c|c|c|c|c|c|c|c|c|}
\hline \multirow{2}{*}{\multicolumn{2}{|c|}{$\begin{array}{l}\text { Occurrence of ketone } \\
\text { bodies in urine during } \\
\text { lactation }\end{array}$}} & \multirow{2}{*}{$\begin{array}{l}\text { Number } \\
\text { of } \\
\text { lactations }\end{array}$} & \multirow{2}{*}{$\begin{array}{l}\text { Days } \\
\text { in } \\
\text { milk }\end{array}$} & \multicolumn{3}{|c|}{ Yield (kg) } & \multirow{2}{*}{$\begin{array}{l}\text { kg milk } \\
\text { per } 1 \text { day } \\
\text { of milking }\end{array}$} & \multicolumn{2}{|c|}{ Content in milk (\%) } \\
\hline & & & & milk & fat & protein & & fat & protein \\
\hline \multirow{2}{*}{$\begin{array}{l}\text { Standard } \\
\text { lactation }\end{array}$} & No & 52 & 302 & 5853 & 253 & 205 & $19.4^{\mathrm{a}}$ & 4.32 & $3.52^{\mathrm{A}}$ \\
\hline & Yes & 98 & 298 & 6183 & 265 & 211 & $20.7^{b}$ & 4.29 & $3.43^{\mathrm{B}}$ \\
\hline \multirow{2}{*}{$\begin{array}{l}\text { Complete } \\
\text { lactation }\end{array}$} & No & 52 & 419 & 7347 & 321 & 264 & 17.5 & 4.42 & 3.60 \\
\hline & Yes & 98 & 391 & 7279 & 316 & 258 & 18.6 & 4.22 & 3.51 \\
\hline
\end{tabular}

Averages designated with different letters differ significantly, ${ }^{A B} P \leq 0.01$, ab $P \leq 0.05$

The data in Figure 1 clearly show that a positive result for the presence of ketone bodies in the urine negatively affected the course of lactation. In the case of cows with negative results, the highest daily yield occurred in the second month after calving and was $0.9 \mathrm{~kg}$ higher than in the first month. In this group, milk yield decreased with each month with the greatest decrease $(2.0 \mathrm{~kg}$ milk) noted between the second and third month after calving. Cows with positive results for the test had a continually descending lactation curve, as the highest yield $(26.8 \mathrm{~kg})$ was noted in the first month after calving. In month two it decreased by $0.5 \mathrm{~kg}$ compared to month one and in the next six months the decreases ranged from 1.9 to $1.3 \mathrm{~kg}$ of milk. The data in Figure 1 also show that cows that were tested negative for ketone bodies had significantly $(P \leq 0.01$ and $P \leq 0.05)$ lower milk yield up to the sixth month after calving. The differences between the groups ranged from 1.2 to $3.4 \mathrm{~kg}$ milk. Other research has also shown higher daily yield in cows that were tested positive for ketone bodies (Januś \& Borkowska 2008). On the other hand, negative effects of ketosis on milk production have been reported by Kondracki et al. (1996), Fourichon et al. (1999) and Jankowska et al. (2005).

In conclusion it should be emphasized that the frequency and intensity of occurrence of ketone bodies in the urine of cows during the first three months after calving was significantly influenced by body condition in the last two weeks before calving by milk yield in standard lactation and on the day the urine samples were taken and by feeding season. The effect of the presence of ketone bodies in the urine on milk yield in standard and complete lactations was small. Cows whose urine contained ketone bodies during the first three months after calving had significantly higher daily milk yield up to the sixth month of lactation. This may indicate that cows with high production potential are more susceptible to ketosis. On the other hand, the presence of ketone bodies in the urine negatively affected the lactation curves of the cows studied. The results obtained may indicate problems in herd management and should serve to eliminate them, in particular by optimising nutrition during the calving period. They may also confirm the important role of herd management in preventing ketosis, not only in high-yield cows but in herds of average productivity as well. 


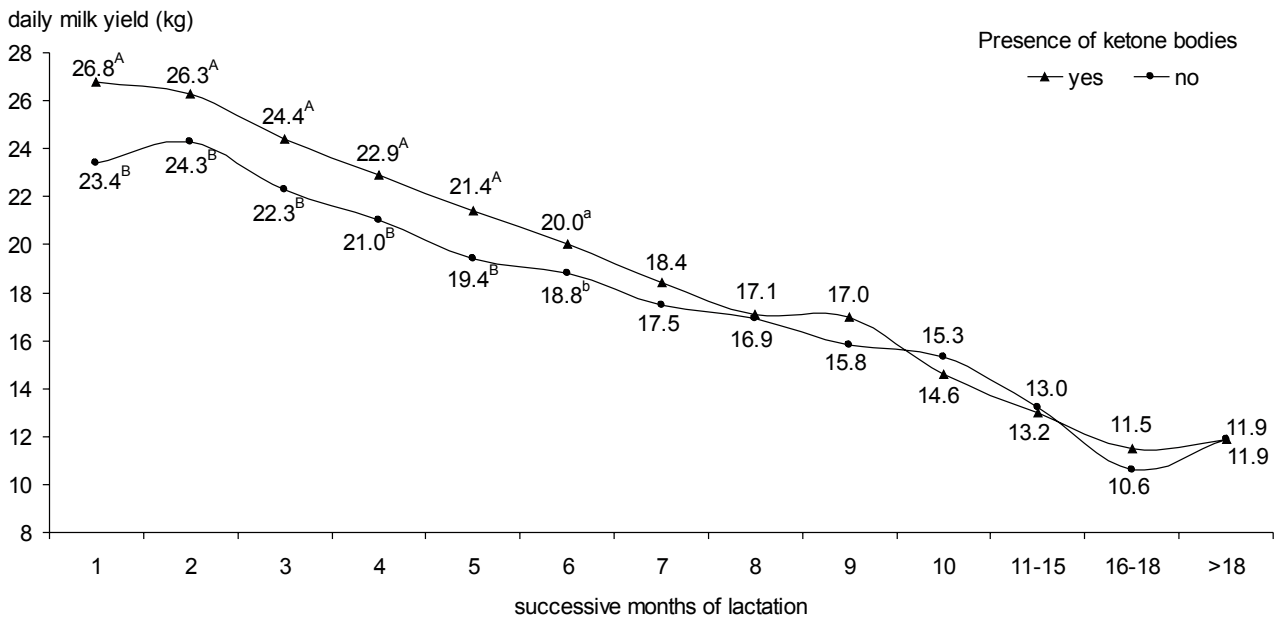

Figure 1

Daily milk yield during lactation of cows with positive and negative results for the ketone bodies (statistically significant differences for successive months at: ${ }^{\mathrm{AB} P} P 0.01$, ab $P \leq 0.05$ )

\section{References}

Bell AW (1995) Regulation of organic nutrient metabolism during transition from late pregnancy to early lactation. J Anim Sci 73, 2804-2819

De Boer G, Trenkle A, Young JW (1985) Glucagon, Insulin, Growth Hormone, and Some Blood Metabolites During Energy Restriction Ketonemia of Lactating Cows. J Dairy Sci 68, 326-337

Filar J (1994) [Evaluation of the usefulness of laboratory tests of blood and urine in the differential diagnosis of spontaneous and dietary ketosis in cows]. Życie Weter 9, 342-345 [in Polish]

Filar J (2001) [Disorders of carbohydrate and fat metabolism in ruminants]. University of Life Sciences in Lublin Publishing, Poland, 5-24 [in Polish]

Fleischer P, Metzner M, Beyerbach M, Hoedemaker M, Klee W (2001) The Relationship Between Milk Yield and the Incidence of Some Diseases in Dairy Cows. J Dairy Sci 84, 2025-2035

Fourichon C, Seegers H, Bareille N, Beaudeau F (1999) Effects of disease on milk production in the dairy cow: a review. Prev Vet Med 41, 1-35

Geishauser T, Leslie K, Tenhag J, Bashiri A (2000) Evaluation of Eight Cow-Side Ketone Tests in Milk for Detection of Subclinical Ketosis in Dairy Cows. J Dairy Sci 83, 296-299

Gillund P, Reksen O, Gröhn YT, Karlberg K (2001) Body Condition Related to Ketosis and Reproductive Performance in Norwegian Dairy Cows. J Dairy Sci 84, 1390-1396

Jankowska M, Sawa A, Pilarska A (2005) Influence of Perinatal Diseases on Cow Milk and Breeding Usefulness. Folia Biol (Krakow) 53 (Suppl.), 79-83

Januś E, Borkowska D (2008) [Occurrence of ketone bodies in cows' urine and its relationship with milk production]. Sci Ann Polish Soc Anim Prod 4, 145-151 [in Polish]

Januś E, Borkowska D, Grzesik K (2007) [Relationship between body condition of cows in dry period and level of their energy reserves and productivity in the next lactation]. Sci Ann Polish Soc Anim Prod 3, 149-156 [in Polish]

Kondracki M, Bednarek D, Cąkała S (1996) [Problems connected with non-infectious diseases in cattle breeding]. Med Weter 52, 350-354 [in Polish] 
Krogh MA, Toft N, Enevoldsen C (2011) Latent class evaluation of a milk test, a urine test, and the fat-to-protein percentage ratio in milk to diagnose ketosis in dairy cows. J Dairy Sci 94, 2360-2367

Kuczaj M, Preś J, Kinal S, Nicpoń J, Łuczak W, Zielak-Steciwko A (2010) [Some factors of dairy cows and calves husbandry, maintenance and feeding influencing their health status and welfare]. Zesz Nauk UP Wroc, Biol Hod Zwierz LXI, 579, 215-228 [in Polish]

Kupczyński R, Adamski M, Falta D, Chládek G, Kruszyński W (2011) The influence of condition on the metabolic profile of Czech Fleckvieh cows in the perinatal period. Arch Tierz 54, 456-467

Markiewicz H, Kuźma K, Malinowski E (2004) [Relation between particular hormones, cytokines and metabolites during the periparturient period in cows]. Med Weter 60, 356-359 [in Polish]

McArt JAA, Nydam DV, Ospina PA, Oetzel GR (2011) A field trial on the effect of propylene glycol on milk yield and resolution of ketosis in fresh cows diagnosed with subclinical ketosis. J Dairy Sci 94, 6011-6020

Minor DJ, Trower SL, Strang BD, Shaver RD, Grummer RR (1998) Effects of Nonfiber Carbohydrate and Niacin on Periparturient Metabolic Status and Lactation of Dairy Cows. J Dairy Sci 81, 189-200

Mordak R, Preś J, Kinal S, Nicpoń J (2009) [Health problems of highly productive dairy cows in the periparturient period]. Med Weter 65, 444-449 [in Polish]

Østergaard S, Gröhn YT (1999) Effects of Diseases on Test Day Milk Yield and Body Weight of Dairy Cows from Danish Research Herds. J Dairy Sci 82, 1188-1201

Polish Federation of Cattle Breeders and Dairy Farmers (PFCB\&DF) (2012) [The results of milk recording in Poland in 2011]. PFCB\&DF Publishing, Warsaw, Poland. http://www.pfhb.pl/?strona=ocena_wyniki_2011. htm [last accessed 06.05.2013] [in Polish]

Rajala-Schultz PJ, Gröhn YT, McCulloch CE (1999) Effects of Milk Fever, Ketosis, and Lameness on Milk Yield in Dairy Cows. J Dairy Sci 82, 288-294

Raś A (1999) [Studies on the effect of energy balance disturbances on the reproduction processes in dairy cows]. Dissertation 18: pp.69. Akad Rol Tech Publishing, Olsztyn, Poland [in Polish]

SAS (2006) User's Guide Version 9.13. SAS Inst. Inc., Cary, NC, USA

Smith TR, Hippen AR, Beitz DC, Young JW (1997) Metabolic Characteristics of Induced Ketosis in Normal and Obese Dairy Cows. J Dairy Sci 80, 1569-1581

Staufenbiel R, Schröder U, Gelfert CC, Panicke L (2003) [Body condition and metabolic stability as basis of high milk yield, reproductive performance, and general health in dairy cows]. Arch Tierz 46, 513-526 [in German]

Stengärde L, Hultgren J, Tråvén M, Holtenius K, Emanuelson U (2012) Risk factors for displaced abomasum or ketosis in Swedish dairy herds. Prev Vet Med 103, 280-286

Wildman EE, Jones GM, Wagner PE, Boman RL, Troutt Jr HF, Lesch TN (1982) A Dairy Cow Body Condition Scoring System and Its Relationship to Selected Production Characteristics. J Dairy Sci 65, 495-501 